\title{
POLICÍA JUDICIAL: A LA BÚSQUEDA DE UN MODELO ADECUADO PARA UNA LUCHA EFICAZ CONTRA EL CRIMEN*
}

\author{
Juan-Luis Gómez Colomer
}

\section{Resumen}

Este trabajo se ocupa de las relaciones entre el Estado y el crimen, a cuyo efecto se hacen diversas sugerencias para lograr un marco organizativo general que sea adecuado para la Policía Judicial. Además, se examina las funciones generales que la misma debe tener en el proceso penal, los límites de la investigación policial y sus consecuencias; así mismo, aborda algunos aspectos complejos de la actuación policial en su calidad de autoridad pública, cuando actúa en la persecución del delito en los momentos actuales. Al final, señala los aspectos mínimos comunes que sí deberían conformar un modelo policial efectivo, tanto desde un punto de vista material, como puramente jurídico.

\section{Palabras claves}

Estado, España, crimen, proceso penal, policía judicial, investigación policial.

\begin{abstract}
This work deals with the relations between the State and crime, for which purpose various suggestions are made to achieve a general organizational framework that is suitable for the Judicial Police. In addition, it examines the general functions that it must have in the criminal process, the limits of the police investigation and its consequences; likewise, it addresses some complex aspects of police action in its capacity as public authority, when it acts in the prosecution of crime at the current time. In the end, it he points out the minimum common aspects that should make up an effective police model, both from a material point of view and purely legal.
\end{abstract}

\section{Keywords}

State, Spain, crime, criminal process, judicial police, police investigation.

\footnotetext{
* Texto de la ponencia presentada en "II Congreso Internacional de Policía Judicial Nuevos Retos", organizado por el Instituto de Criminalística, Escuela Mayor de Derecho de la Universidad Sergio Arboleda, Bogotá, el día 20 de octubre de 2017.

${ }^{*}$ Licenciado en Derecho y graduado en Criminología, Universidad de Valencia; Profesor de la Universidad Jaume I de Castellón, España; E-mail: colomer@dpu.uji.es
} 


\section{Estado, Policía y crimen: una introducción}

Explicar la actividad de la policía en relación con la investigación del delito es un tema complejo, primero, porque ella, en la generalidad de los países, no suele dedicarse exclusivamente a tareas de investigación del crimen, con lo que su actividad puede enmarcarse en varias instituciones jurídicas y, por tanto, tener diferentes naturalezas jurídicas; $\mathrm{y}$, segundo, porque requiere, además de un catálogo preciso en que se definan sus funciones, explicitándose los límites de su actuación con claridad, de una organización administrativa, generalmente de dimensiones enormes, que sea capaz de cumplir con eficacia las funciones que tiene asignada.

Desde el primer punto de vista, hay un acuerdo bastante generalizado en considerar a la policía como una institución absolutamente necesaria para investigar con eficacia el crimen y que se pueda así un día castigar a su autor en cumplimiento de la pena impuesta por un tribunal de justicia. Es más, se considera que la policía es pieza imprescindible del engranaje articulado para la persecución del delito por el Estado, siendo indiscutiblemente en todos los países autoridad pública de persecución.

Pero con la misma nitidez se descubre a continuación, desde el segundo punto de vista, que aun gozando de la extraordinaria ventaja de ese importante acuerdo, cada país tiene dificultades, a veces enormes, para organizar administrativamente la policía de manera que pueda cumplir adecuadamente con sus fines procesales penales, no se sabe muy bien si a causa de la complejidad de la institución, de la falta de claridad en el Estado sobre cómo hacerlo exactamente, o incluso porque hay interés en que verdaderamente no funcione.

Dado que este texto se escribe específicamente para un congreso internacional sobre policía judicial que fue realizado en Bogotá, siempre que sea oportuno me referiré a América Latina, pues presenta además el aliciente de que todos sus países han adoptado ya el modelo adversarial norteamericano de enjuiciamiento criminal, lo que nos da la ventaja de poder tener una cierta identidad en el tratamiento. Una manera de resolver adecuadamente ambas cuestiones es fijarse en los modelos existentes en los países democráticos más avanzados.

En mi opinión, tener o seguir un modelo policial es necesario absolutamente para que la justicia penal funcione con corrección, de la misma manera que lo es el saber qué modelo de organización judicial queremos en cada uno de nuestros países. Por tanto, para que los ciudadanos sepan que el tercer poder del Estado realmente es tal en una democracia, garantizador objetivamente de la paz social y de la convivencia pacífica, y subjetivamente de los derechos de los ciudadanos vulnerados por el delito, satisfaciendo en la medida de lo posible a la víctima y castigando a su autor, es requisito sine qua non que exista la policía, porque como hemos dicho sin ella el descubrimiento del crimen y de quién lo ha cometido es prácticamente imposible, y ése es el principio del camino para alcanzar esas metas.

En América Latina, a la hora de volver a la democracia y reorganizar la fuerza policial, han influido dos modelos policiales absolutamente distintos: uno, el anglo- 
sajón, en el que en su origen la policía se configura como un garante de los derechos de los ciudadanos, solo sujeta a la ley, con poderes limitados, siendo muy normal su descentralización (al servicio del poder local) y la falta de coordinación entre todos los cuerpos existentes. Cuando fuese necesario el uso de la fuerza, actuaría el ejército. Y, otro, el modelo europeo continental, en el que en origen la policía es un instrumento del poder político (centralidad), estando en parte militarizada (bien armada y acuartelada), sustituyendo internamente al ejército y estando profesionalizada.

Ambos modelos persiguen controlar el crimen, pero existen diferencias claras, que parten de estar configurados los dos con bases culturales distintas. Sin embargo, fue el diseño anglosajón, con la creación de la Policía Metropolitana de Londres a principios del siglo XIX, concretamente en 1829, el que acabó influyendo en el continental. Pero la policía se creó en muchos países europeos con regímenes absolutistas 200 años antes. Por ejemplo, y por lo que hace referencia a mi país, la Santa Hermandad en Castilla, creada en 1476, se reconoce como la más antigua del mundo, aunque el precedente directo del modelo actual se creó en España en 1824. Se puede decir, por tanto, que el modelo continental es más antiguo, pero menos influyente en el diseño actual de la policía, en donde se ha desarrollado mejor el modelo anglosajón.

Es evidente que hoy ninguno de los dos se articula exclusivamente con base en esas raíces, ante la complejidad de la vida moderna y el disparatado aumento de la criminalidad organizada, la más peligrosa de todas [la policía inglesa lleva armas en concretos momentos y situaciones, tiene determinadas legalmente sus funciones desde la PACE - Police and Criminal Evidence Act, de 1984, y es instrumento de la fiscalía (CPS - Crown Prosecution Service) creada en 1985, para la investigación del crimen, lo que ha conllevado además una visible centralización; y por lo que respecta a la policía de Estados Unidos, su complejidad y fragmentación debida a la enormidad del territorio y el crecimiento de la población en determinadas ciudades, la hicieron evolucionar en forma distinta, primero en los estados, y luego en la administración federal, con la creación en 1908 del FBI - Federal Bureau of Investigation, orientándose hacia una gran profesionalización].

Pues bien, partiendo de ambos modelos, que tienen hoy muchos puntos en común, como la profesionalización de sus miembros, la primera pregunta debe ser en consecuencia qué policía queremos para una investigación del delito eficaz. Desde mi perspectiva la policía que importa es la que, como autoridad pública, tiene el deber de investigar el crimen. Por tanto, debo partir necesariamente, expuesto lo anterior, de una perspectiva distinta, que no es otra que la legal, desmenuzada en todos sus contenidos. Pues bien, aunque me limite en este breve análisis a algunos aspectos procesales penales, no hay que olvidar que el modelo policial se nutre legalmente de tres componentes muy difíciles de desligar entre sí, a saber, el constitucional, el administrativo y el procesal penal.

El componente constitucional es el fundamental, en tanto en cuanto nos delimita, o nos debe delimitar, la estructura básica de la organización policial (por ejemplo, creando una verdadera policía judicial, separándola de la policía administrativa y 
distinguiéndola sobre todo del ejército allí donde lo haya y tenga funciones de prevención, grave problema histórico en países como Bolivia, Colombia o Chile); las clases de policía que el Estado quiere tener (en función de si es federal o no, así como lo relativo a las policías geográficamente más limitadas y la coordinación institucional entre ellas, cuestión más importante de lo que se cree en países federales como Argentina, Brasil y México); las líneas básicas de actuación en el proceso penal (investigar el delito, descubrir a su autor); y los principios a que se somete en su actuación, quedando obligada, en particular, a respetar los derechos de los ciudadanos, sobre todo los del inculpado.

A su vez, el componente administrativo es de una gran trascendencia también, especialmente en aquellos países en los que la policía judicial es la misma que la policía administrativa, porque debe definir las reglas de actuación cuando se auxilia al poder judicial y cuando no, teniendo en cuenta que para los ciudadanos el papel preventivo de la policía, que se concreta en el mantenimiento del orden público y de la seguridad ciudadana, es muy importante. También nos indica la estructura jerárquica de funcionamiento, que indiscutiblemente debe formar parte del modelo policial.

Finalmente, aparece el componente procesal penal, que es el que importa aquí, pues la policía actúa entonces en funciones de represión del delito. En este sentido, un modelo policial, cualquier modelo policial válido, tiene que articular estos tres aspectos de manera adecuada para que la institución policial pueda cumplir sus fines con eficacia. Si la policía no es efectiva, algo importante falla en ellos.

Voy por consiguiente a proponer a continuación algunas cuestiones que pueden contribuir al menos a un conocimiento pragmático de que el modelo policial debe formarse, completarse o perfeccionarse cuanto antes en cada país, advirtiendo previamente que no entraré en cuestiones administrativas (prevención del delito), y que el fin de las páginas que siguen no es definir un modelo policial abstracto, válido para cualquier país en general, sino explicar qué debe prever necesariamente el mismo para que la actuación de la policía en el proceso penal sea realmente eficaz en cualquier país. Me importan por tanto los contenidos concretos de la institución, no los ideales de la misma. Tampoco quiero criticar modelos ya existentes o la configuración propia de cada país consultado en Latinoamérica, ni mucho menos importar un modelo extranjero, de Europa o de Estados Unidos. El Estado que haya materializado una opción no tiene derecho a pensar por esto solo que la suya es la mejor y que por ello debe exportarla. Solo me detendré, en consecuencia, en los aspectos mínimos comunes que sí deberían conformar en mi modesta opinión un modelo policial efectivo, tanto desde un punto de vista material, como puramente jurídico.

El verdadero problema, el punto de partida de todos los demás aspectos discutidos, es que no existe realmente un modelo policial en América Latina, es decir, que no hay una concepción estatal sobre la organización de la policía como auxiliar de los tribunales y de los fiscales para la investigación del crimen o, si la hay, sus contenidos no están ni bien perfilados ni bien definidos, o lo están de tal manera que la policía es absolutamente ineficaz en su trabajo. Más preocupante es, sin embargo, que no 
parece deducirse de las políticas respectivas de cada uno de los países que este importante problema esté en vías de solución, aunque hayan existido reformas más o menos amplias de la Policía en algunos países.

Opino así porque las quejas sobre su ineficacia son, más que comunes, unánimes, lo que revela que la organización es deficiente. Además, cuestiones clave como la definición de su relación con el poder ejecutivo y con el poder judicial no están, a veces, ni siquiera esbozadas. Finalmente, se constata que los niveles de corrupción, impunidad y arbitrariedad son altísimos, lo que implica desdén o tolerancia estatal incompatible con un modelo policial propio de un Estado de Derecho.

\section{Sugerencias para un marco organizativo general adecuado de la policía judicial}

Es preciso, en consecuencia y ante todo, que el Estado elabore un marco organizativo general adecuado en el que implementar el modelo por el que haya optado. La concepción, articulación y puesta en práctica de los contenidos de un modelo policial es, en efecto, responsabilidad del Estado, porque él tiene atribuidas por decisión popular en una democracia las funciones de garantizar la seguridad de los ciudadanos y la paz social, por un lado, y la investigación del crimen y de su autor por otro. Para cumplir con la primera crea la policía administrativa; para con la segunda crea los jueces y los fiscales, pero haciendo auxiliar suyos a la policía, sea judicial estrictamente o no.

Las precisiones al respecto para lograrlo son importantes y nada se debe dejar al azar. En mi opinión un modelo policial válido para la investigación del crimen debería circunscribirse a dos tipos de cuestiones de suma trascendencia, una de carácter organizativo y otra de carácter funcional. Trataremos, ahora, el modelo policial como organización y dejaremos para el epígrafe siguiente el aspecto funcional del modelo. En este sentido, debe crearse legislativamente ante todo una verdadera policía judicial, sea éste el nombre u otro equivalente. Por policía judicial entiendo una policía verdaderamente autónoma respecto a la policía administrativa u otras clases de policía, por tanto, no subordinada al poder ejecutivo (ministerio del interior), al servicio exclusivo de la justicia penal. El Organismo de Investigación Judicial de Costa Rica podría ser un buen ejemplo de partida.

Como tal, la policía judicial debe ser organizada de manera que pueda cumplir perfectamente con las funciones a las que me referiré luego, lo que implica decidir de quién depende jerárquicamente, a qué régimen de responsabilidad se somete y qué grado de profesionalización se desea alcanzar.

En cuanto a la jerarquía la decisión sobre de quién depende jerárquicamente la policía judicial debe ser a favor del juez o del fiscal competente para la investigación, o de ambos como ocurre en algunos países. En ningún caso debe depender del poder ejecutivo, frente al que las normas vigentes en cada país y, sobre todo, su práctica, deben garantizar una verdadera autonomía. La opción de incardinarlo en el poder judicial o en la fiscalía general, con matices, parece aceptable. 
Esas leyes deben regular con nitidez, y, concretamente, el principio de subordinación oficial y el principio de exclusividad de la actuación de la policía judicial, de forma que, por el primero, sus miembros solo dependan de las autoridades públicas de persecución que estén por encima de ellos, a saber, solo del juez o solo del ministerio público, o solo de ambos, como queda dicho, incluso preferentemente solo de uno de ellos para evitar los problemas consustanciales a tener un mando bicéfalo; mientras que, por el segundo, los miembros de la policía judicial solo podrán realizar tareas que le sean propias, o las derivadas de las mismas, no siendo posible que puedan desarrollar otras, v.gr., de tipo preventivo, ni tampoco que puedan ser apartados de una actuación o investigación criminal para efectuar otras actividades de naturaleza administrativa.

En relación con la responsabilidad, el miembro de la policía judicial es un funcionario público o figura equivalente. Por ello el régimen jurídico general de su actividad como tal le es plenamente aplicable, aunque esté luchando contra el crimen, o precisamente por ello. En particular debo destacar que los actos que realicen, por acción u omisión, que no estén amparados por la legalidad vigente en cada país, deben dar lugar a responsabilidad personal. Pero ha de existir también una responsabilidad objetiva de la administración por los daños patrimoniales que la actuación no ajustada a derecho de la policía judicial pueda causar.

Que el policía esté sujeto a responsabilidad personal disciplinaria, civil y penal, y que se haga efectiva cuando se produzca la infracción, es una garantía para acabar con la corrupción, la arbitrariedad y la impunidad de los miembros de la policía. Por eso no es de extrañar que en aquellos países de América Latina en los que más corrupción, arbitrariedad e impunidad policiales se dan, o bien las normas sobre responsabilidad sencillamente no existen, o bien si las prevé el ordenamiento jurídico no se aplican en absoluto.

En cuanto a la profesionalización, el modelo policial finalmente debe sentar las bases para que la policía judicial esté totalmente calificada. Esto implica garantizar tres ámbitos concretos: Primero, que la policía judicial goce de una formación jurídica adecuada, particularmente a nivel de Derecho penal, Derecho procesal penal y Derecho constitucional, lo que presupone un nivel cultural general mínimo, que no se suele dar en los países latinoamericanos analizados, atendidos los perfiles policiales, con excepción de algunos países en lo relativo a los mandos; segundo, que disfrute de una gran formación científica, estando bien equipada técnicamente, de manera que pueda luchar eficazmente contra todo tipo de crimen, especialmente contra la gran delincuencia (la de la criminalidad organizada), uno de los fenómenos actuales más preocupantes, gozando de personal y de medios plenamente capacitados para ello, en plena colaboración con las Policías de otros países, lo que requiere ineludiblemente unas dotaciones presupuestarias adecuadas para ello; y tercero, que perciba salarios dignos, quizás la principal arma en la lucha contra la corrupción, que le haga sentirse importante en su trabajo sin preocuparse por tener que buscar ingresos extras, a veces de manera tan fácil como ilegítima. 
Resueltas estas tres cuestiones de manera satisfactoria, el modelo es ya visible y puede quedar garantizada una correcta operatividad, especialmente en la lucha contra el crimen.

\section{Las funciones generales de la policía judicial en el proceso penal}

En ese sentido, este modelo implementado en un marco de organización y actuación debe dar un paso más y articular legalmente y con gran precisión las funciones de la policía judicial en el proceso penal. Es la parte del modelo policial contemplado como estructura funcional, a la que nos referíamos en el epígrafe anterior.

Los cometidos de la policía judicial son muy variados. Teóricamente no debería ser decisivo en esta cuestión que el proceso penal estuviera instruido por un juez o por un fiscal, puesto que el crimen y sus autores deben ser descubiertos en ambos casos igualmente, si bien en América Latina, a causa de precedentes lamentables de sobra conocidos que afectan a la corrupción judicial, se ha preferido el cambio a la figura del fiscal instructor. Sea como fuere, lo cierto es que, en los últimos tiempos, por influencia anglosajona sin duda alguna, las principales funciones de la policía judicial se suelen fijar en una fase del proceso específica previa a la intervención del juez y del fiscal, anterior incluso a la propia incoación formal del proceso. Esto no aparece siempre claramente así en todos los códigos procesales penales de los países latinoamericanos analizados, aunque en algunos sí, como en Cuba, o como se pretende con el nuevo Código Procesal Penal de Nicaragua de 2001, pero en los demás se deduce inequívocamente de sus disposiciones. Positivamente en cuanto a su formulación, los arts. 200 a 212 CPP 2004 (L. 906/2004) de Colombia.

Con ello se da reconocimiento legal a la dirección material de la investigación, es decir, se otorga cobertura normativa a la actuación verdaderamente instructora de la policía judicial, porque ni el juez ni el fiscal pueden hacerlo en la práctica, ante su falta de tiempo, de medios y en muchos casos de preparación técnica. Por eso, sin duda, dijo con gran acierto el gran jurista alemán Kern hace muchos años que la fiscalía sin la policía es como una cabeza sin manos, no puede actuar sin ella.

Pero es necesario el control, porque la investigación real no puede descargarse en manos de la policía judicial sin que deba dar cuenta de sus actos. Esto puede conllevar el riesgo de una gran oposición por parte del poder político, porque puede manejar mucho más fácilmente a la policía que a los jueces, pero es necesario para que exista una auténtica justicia penal. Pues bien, el modelo policial debe garantizar que la policía judicial pueda realizar con efectividad las funciones siguientes:

En relación con el autor del delito, debe averiguar quién o quiénes son los responsables de los hechos criminales, actuando por iniciativa propia en cumplimiento de la ley como respuesta a las denuncias ante ella presentadas, o por orden de la autoridad judicial o fiscal. En caso de estar legalmente permitido por mor del principio de proporcionalidad, deberá detener al presunto autor y ponerlo a disposición judicial (o fiscal) tras la realización de las diligencias pertinentes, básicamente el interrogatorio policial del detenido, que es el acto más delicado puesto que afecta a derechos 
constitucionales del mismo irrenunciables, como el derecho a su integridad física y psíquica, el derecho a la presunción de inocencia, el derecho a la defensa por abogado, y el derecho a ser informado de la acusación.

Además, en relación con el delito cometido el modelo policial debe hacer posible que la policía judicial pueda averiguar de manera profesional, técnicamente adecuada y con pleno respeto al principio de legalidad, las circunstancias que rodean la comisión del hecho punible, practicando los actos de investigación necesarios para ello, incluidas las llamadas diligencias de prevención o primeras actuaciones a realizar una vez cometido y descubierto el delito (protección de la víctima, recogida de pruebas y de piezas de convicción como el arma homicida, identificación del presunto autor y, en su caso, detención del mismo, v. infra). Se trata de dominar a la perfección la escena del crimen para cumplir adecuadamente con estos fines.

Así mismo, en relación con la víctima del delito la policía judicial debe estar preparada para auxiliarle inmediatamente, lo que incluye proporcionarle rápidamente atención médica en su caso. Un aspecto decisivo desde el punto de vista jurídico es sin duda obligar a la policía judicial a que instruya a la víctima sobre sus derechos de manera que en la práctica sea verdaderamente eficaz la protección (derecho de información de la víctima). Pensemos en colectivos que por diferentes razones merecen una especial tutela procesal penal (víctimas especialmente vulnerables), como menores desamparados o desvalidos, incapacitados y mujeres maltratadas, víctimas de la violencia de género u objeto de abusos sexuales, y comprenderemos enseguida la importancia de esta función. La Directiva 2012/29/UE del Parlamento Europeo y del Consejo de 25 de octubre de 2012 por la que se establecen Normas Mínimas sobre los Derechos, el Apoyo y la Protección de las Víctimas de Delitos, y por la que se sustituye la Decisión Marco 2001 / 220 / AI del Consejo, ha tenido una gran influencia en Europa, fruto de la cual es la Ley 4/2015 española del Estatuto de la Víctima del Delito, que mejora la situación jurídica y derechos de las víctimas del delito, sobre todo de aquéllas que no desean ser parte en el proceso penal.

Todo ello sin perjuicio de otras funciones de ejecución de órdenes judiciales (que concretaremos infra), y de auxilio al juez o al fiscal, que, si bien son igualmente importantes y que por esto mismo deben estar garantizadas por el modelo policial, carecen ahora de mayor relevancia.

\section{Los límites de la investigación policial y sus consecuencias}

Hasta aquí el modelo nos debe ayudar claramente a resolver el problema de la eficacia técnica de la policía judicial, pero también ha de contribuir sin flaquear un ápice a garantizar la eficacia jurídica de su actuación. En efecto, la incidencia mayor del modelo policial que nota la ciudadanía se produce en el desarrollo de la fase de investigación de cualquier proceso penal, porque el sistema de enjuiciamiento criminal tiene que fijar determinados aspectos de la actuación de la policía judicial en esa fase, lo cual significa que el modelo policial y la legislación procesal penal deben actuar coordinadamente. 
La principal cuestión que se plantea, sin embargo, en el proceso penal propio de un Estado de Derecho no es qué puede (o debe) hacer la policía judicial en la investigación del crimen, sino qué no puede (o no debe) hacer. El diseño debe por consiguiente fijar los límites de la investigación criminal que la policía puede llevar a cabo, lo que nos lleva a considerar los actos restrictivos de derechos fundamentales que puede practicar. Por tanto, el primer límite se encuentra en la propia Constitución política. Esto, a su vez, nos conduce a un mundo jurídico muy particular que tiene igualmente un punto de partida, un contenido y unos efectos muy determinados, a veces poco claros en las legislaciones latinoamericanas consultadas.

Llamo ahora la atención sobre el hecho de que me refiero a toda una constelación de actos procesales practicados por la policía en función de órgano auxiliar de la justicia penal de los que depende el éxito, no de la investigación criminal en curso, sino del propio proceso penal. Ello, porque la policía judicial debe saber indubitadamente cuándo puede actuar y cuándo no (prueba prohibida); cuándo puede detener y cuándo no (detención ilegal, habeas corpus); cómo debe investigar (prueba inútil); qué enfoque táctico debe dar a su actuación frente a la macro delincuencia organizada, el terrorismo y el narcotráfico, principalmente, sin excluir a mafias, corrupción pública, trata de mujeres, pornografía infantil, subversión y rebelión, etc. (introducción de informantes, policías infiltrados, testigos de auditur), lo que en algún país como Perú ha dado lugar a numerosa legislación de excepción; y cuáles son los límites de su actuación frente a determinados actos garantizados muy importantes (escuchas telefónicas, injerencias corporales, entradas y registros en moradas ajenas, interrogatorio de sospechosos e inculpados, etc.). El más mínimo error o la más pequeña vulneración de la norma en estas cuestiones, además de la frustración de la investigación y del proceso penal (posible sentencia de condena), implicaría sobre todo y en definitiva el fracaso más rotundo del Estado de Derecho.

\section{El punto de partida.}

Pues bien, el punto de partida es ése mismo Estado de Derecho pues en nuestras democracias no podía ser de otra manera. En ese sentido, el Estado de Derecho no permite que en la investigación del crimen valga todo. Como dijo con precisión admirable el Tribunal Supremo Federal alemán en sentencia del catorce de junio de 1960, "no es un principio de la Ley Procesal Penal el que se tenga que investigar la verdad a cualquier precio". El juego procesal debe ser limpio (fair), se diría desde el mundo anglosajón. Por ello en su actuación la policía judicial debe vigilar estrechamente en la fase de investigación del crimen, no solo que las garantías procesales se cumplen y que los derechos fundamentales consagrados en la Constitución, sobre todo los del imputado, se respetan, sino que también y ante todo, debe cumplirlas y preservarlos ella misma.

Esto significa, en definitiva, que el Estado no puede reaccionar contra el delito igualándose al delincuente incluso actuando tan bárbaramente como él, sino mediante un juicio debido, ordenado, objetivo, imparcial y justo. Pero es cierto que en ocasiones es difícil contener los límites de la reacción contra el delito y el delincuente, 
de ahí la existencia de dos disposiciones claves que protegen a los particulares frente a aquellos Poderes, que constituyen a su vez límites concretos ciertos de la actuación de la policía judicial:

En primer lugar, la tajante prohibición de la tortura, medio históricamente utilizado para obtener la infalible confesión del imputado, tutelando a éste debidamente en caso de infracción (Convenio de Nueva York de 1984, además de, en muchos casos, normas constitucionales expresas de los países latinoamericanos democráticos, sin perjuicio de las regulaciones específicas de los códigos penales y códigos procesales penales respectivos).

Y, en segundo lugar, el establecimiento de dos reglas probatorias significativas: La libre apreciación de la prueba, y la presunción de inocencia (art. 6.2 del Convenio Europeo para la Protección de los Derechos Humanos y de las Libertades Fundamentales de 1950, art. 8.2 del Pacto de San José de 1969, también consagrada en muchas constituciones europeas y americanas), por medio de las cuales las pruebas se valoran con arreglo a criterios racionales y sin valor tasado previo ninguna de ellas, presumiendo a todo imputado inocente hasta que se demuestre su culpabilidad. El modelo policial debe incidir especialmente en este aspecto, que se traduce en propiciar una formación jurídica excelente a los miembros de la policía judicial, incluidos cursos de reciclaje periódicos, sobre todo de explicación de la Jurisprudencia que las respectivas cortes supremas estén formando al respecto. Es el efecto disuasorio (deterrent effect), tan importante para ordenar la actividad de la policía al cumplimiento estricto de la ley y evitar exclusiones probatorias por infracciones constitucionales en su obtención.

\section{El contenido.}

En cuanto al contenido de la actuación de la policía debe decirse que es muy amplio, pues tiene que ver con la aplicación de normas procesales penales, complementadas con una adecuada técnica policial, en la investigación del delito, cualquier delito, lo que significa un abanico de posibilidades de por sí ya bastante extenso, frente a su posible autor, cualquier autor, lo que nos lleva todavía más allá. Me limitaré por ello al aspecto esencial, a saber, los límites probatorios de la actuación policial o, lo que es lo mismo, la llamada prueba prohibida o ilícita.

El ejercicio de la coacción estatal en el proceso penal, necesaria -como es lógico para la persecución del delito y enjuiciamiento del delincuente-, atenta contra determinados derechos fundamentales muy importantes de los particulares, aunque con justificación por ello mismo. Así, por ejemplo, la detención y la prisión provisionales van contra el derecho de libertad; las medidas de aseguramiento de objetos o prestación de fianzas, atentan contra el derecho de propiedad; el registro domiciliario, vulnera el derecho a la inviolabilidad de domicilio; y la grabación de comunicaciones privadas lesiona el derecho al secreto de las mismas; etc.

Estas relaciones entre el Derecho procesal penal y el Derecho constitucional tienen, desde otro punto de vista, una conexión ideológica evidente, puesto que el proceso 
penal acoge siempre en su seno las condiciones políticas de la sociedad en que se ha de desarrollar, lo que significa que nuestro proceso penal es el espejo en el que se miran los preceptos constitucionales, reflejando la verdadera naturaleza del régimen político imperante. Aunque tales injerencias en los derechos fundamentales aparezcan justificadas, y las leyes las rodeen de las máximas garantías (fundamentalmente, intervención y aprobación del juez), los sistemas que escogen la jurisdicción constitucional concentrada suelen permitir que un tribunal (corte) constitucional pueda controlar y enjuiciar las vulneraciones de los derechos fundamentales consagrados por la Constitución, no solo los procesales penales, y a pesar de haber sido ordenadas por un juez, mediante el proceso de amparo o equivalente.

Obsérvese, pues, que siendo el Derecho penal un derecho de protección individual y social de bienes jurídicos entroncados con principios básicos de todas las constituciones democráticas, el Derecho procesal penal se convierte en el garante del Estado de Derecho consagrado por esa misma constitución. Si se piensa desde esta perspectiva en las funciones de la policía judicial, la relevancia de su actuación es en la práctica diaria enorme.

Por eso, cualquier trasgresión en la actuación policial con ocasión de la investigación de un delito, que afecte a un derecho fundamental del imputado y que no se haya realizado de conformidad con las disposiciones de la constitución política y del código procesal penal correspondientes (en general y sin matices: autorización judicial y proporcionalidad), conlleva comúnmente la nulidad de la práctica de la prueba en sí y del resultado probatorio obtenido, porque estamos ante una prueba prohibida o ilícita, lo que puede implicar a su vez la ausencia total de prueba en la causa y, por tanto, la puesta en libertad obligada de un auténtico criminal, salvo que las leyes o la jurisprudencia de cada país hayan consagrado elementos de escape, como la conocida teoría del descubrimiento inevitable, que también tiene su propia constelación de problemas y por consiguiente no puede considerarse plenamente aceptable.

Hay muchos supuestos específicos en concreción de lo anterior regulados por los códigos procesales penales. Por ejemplo, recordemos, la detención, las declaraciones ante la policía, el derecho de defensa, la entrada y registro, la intervención de las comunicaciones privadas, en donde están en juego varios derechos fundamentales del imputado, investigado o acusado. No tengo espacio para referirme a todas ellas, por eso trataré ahora los llamados actos contra la integridad corporal y la utilización de alta tecnología para la investigación del crimen, porque me parecen los de mayor trascendencia en la actualidad. Me fijaré en mi país como punto de partida, a efectos de facilitar una exposición más ordenada.

\section{Los dos conjuntos de actuaciones.}

En este sentido voy a considerar dos tipos de actuaciones:

Los actos contra la integridad corporal, en especial, el cacheo, el ADN y el test de alcoholemia. 
El art. $15 \mathrm{CE}$ reconoce, a todos, el derecho fundamental a la vida y a la integridad física y moral. Sin embargo, la integridad física puede verse afectada por determinadas medidas de investigación criminal, generalmente además no reguladas por la ley en forma expresa, por ejemplo, cuando son necesarios reconocimientos corporales para averiguar las circunstancias del delito y la posible responsabilidad de sus autores. Sorprende de manera muy negativa esta falta de regulación en tema tan importante como delicado, sobre todo teniendo en cuenta la ingente cantidad de reformas procesales que se han producido en 2015. El papel de la policía judicial no queda, por tanto, en líneas generales, convenientemente regulado.

Pues bien, en estos casos, convendría fijar una serie de presupuestos, acordes con la naturaleza de derecho fundamental, que en todo caso no dejan de ser una opinión personal del autor de estas páginas. Concretamente, los actos de investigación que significan injerencias a la integridad corporal deberían: $1^{\circ}$ ) Ser acordados exclusivamente mediante auto del JI, salvo que el titular del derecho preste su consentimiento o existan razones de urgencia muy fundadas, en cuyo caso pueden ser acordados por el ministerio fiscal o la policía judicial, requiriéndose la ratificación judicial a posteriori; $2^{\circ}$ ) ser practicados por personas expertas o profesionales (v.gr., la policía judicial científica, el médico forense u otro médico cualificado, etc.); $3^{\circ}$ ) en tanto puedan reconducirse a actividades periciales, deberán ser de aplicación las normas previstas para este acto de investigación; y $4^{\circ}$ ) en ningún caso se debe acordar la medida cuando haya peligro grave para la salud.

Dicho esto, las diligencias pueden ser muy variadas:

- Extracciones de sangre (v. gr., en delitos contra la libertad sexual, arts. 178 y ss. CP español).

- Análisis de líquidos humanos (saliva, semen, orina, etc.), y punciones pulmonares o medulares. Merece destacarse aquí la toma de muestras para averiguar el ADN de una persona. El ácido desoxirribonucleico (ADN, o DNA en sus siglas en inglés) es una huella o vestigio de naturaleza biológica que permite averiguar un hecho criminal y sus circunstancias, así como su posible autor o autores. Se descubrió en 1953 y se utilizó procesalmente por vez primera en Inglaterra en 1985 (caso Enderby). Forma parte de las llamadas pruebas científicas. Esta prueba afecta a varios derechos constitucionales del investigado (integridad física, intimidad, a no declarar contra sí mismo, defensa). Como puede practicarse a efectos meramente identificadores y también de archivo (nunca del ADN codificante) en una base de datos específica, los derechos fundamentales afectados pueden variar.

Por lo que hace referencia a España, la LECRIM la regula muy parcialmente en los arts. 326, 363 y 778.3, así como en su DA-3a. La LO 10/2007, de 8 de octubre ha regulado la base de datos policial sobre identificadores a partir del ADN; la legislación europea sobre el tema es ya muy amplia, destacando el Tratado de Prüm de 2005. 
La práctica de la prueba la inicia la policía científica tomando las muestras, huellas, restos o vestigios biológicos; y se desarrolla por un equipo técnico forense altamente cualificado integrado en un laboratorio oficial. El control de la cadena de custodia juega aquí un papel fundamental. No es una prueba documental como dice la ley española, sino pericial, que se valora libremente por el juzgador conforme a los límites jurisprudenciales establecidos para estas pruebas por la jurisprudencia. Es una prueba que puede ser practicada en algunos casos sin abogado defensor, por ejemplo, cuando esas huellas o vestigios están abandonados o consiente el propio imputado; también puede ejecutarse en contra de la voluntad del imputado mediando autorización judicial.

- Radiografías, electrocardiogramas o encefalogramas.

- Tactos vaginales o anales (v.gr., en delitos contra la salud pública, arts. 359 y ss. CP español).

- Reconocimientos corporales (v. gr., en delitos de aborto, arts. 144 y ss. CP, LO 2/ 2010, de 3 de marzo, para España).

- Los test psiquiátricos o psicológicos.

- Los test de alcoholemia y de estupefacientes en delitos contra la seguridad del tráfico (para España, art. 379.2 CP y arts. 12 LTraf y 20 a 28 Rto.LTraf).

Su ejecución corresponde a la policía judicial, conforme a las normas previstas en la LECRIM, la LTtraf y a las técnicas policiales apropiadas. El TC español, que admite la validez de este medio de investigación (y de prueba), entendiendo que no viola derecho fundamental alguno, ha exigido especiales garantías para que el test pueda en su día convertirse en prueba, y fundamentar de este modo la posible sentencia de condena.

Así, el posible infractor, que está obligado a someterse al test una vez es requerido para ello en el control policial correspondiente, tiene derecho a ser informado de que puede someterse a un segundo examen trascurrido un tiempo, y a análisis de sangre, $y$, en todo caso tiene derecho de defensa, sobre todo si el control implica detención policial, y a que los miembros de la policía judicial que realizaron el test se ratifiquen luego en el juicio oral (v. SS TC 100/1985, 3 octubre; 145/1987, 23 septiembre; y 3/1990, 15 enero, entre otras).

Finalmente, debe quedar fuera de toda duda que en caso de inconsciencia del imputado, la extracción de sangre requiere sin excepción alguna autorización judicial, dada la imposibilidad de prestar su consentimiento el afectado en un sentido o en otro. Obsérvese, por tanto, la enorme importancia que tiene la actuación de la policía judicial en la práctica de la mayoría de estos actos de investigación. De ahí la necesidad, una vez definido el modelo, de una regulación precisa y, hasta cierto punto, exhaustiva, que permita fijar con absoluta claridad sus obligaciones y los límites de su intervención. 


\section{La utilización de alta tecnología para la investigación del crimen.}

El crimen se ha desarrollado enormemente en los últimos tiempos, especialmente bajo la creación de grupos organizados, es decir, en su modalidad de criminalidad organizada, que tiene el dinero suficiente como para estar a la última en cuanto a la más moderna tecnología, lo que obliga al Estado, si realmente quiere ser eficaz en su lucha contra ella, a utilizar las mismas armas en la defensa de la convivencia pacífica de sus ciudadanos y de los derechos de los mismos. Para ello, la dotación tecnológica de la policía judicial al más alto nivel es imprescindible.

Ahora bien, así como la utilización por el crimen obliga a una determinada protección de la ciudadanía honrada, no es claro que con la utilización de los mismos medios el Estado pueda dar una respuesta jurídicamente impecable, porque los nuevos instrumentos para la investigación del crimen que utilizan alta tecnología son muy contundentes, algunos verdaderamente agresivos, y ello implica siempre peligro de poner en cuestión los derechos fundamentales de los ciudadanos, riesgo al que no es en absoluto ajena la policía judicial, y de ahí nuestro breve tratamiento en estas páginas.

En España, que, insisto, sigo tomando como ejemplo, se ha reformado la LECRIM en 2015 con este fin, cuya característica general es la limitación de derechos constitucionales. $\mathrm{Al}$ respecto diré que:

En primer lugar, la justificación de su introducción es plausible si se considera la protección de la sociedad frente a la altísima preocupación social que causan las nuevas formas de delincuencia, que utilizan todos los avances tecnológicos para cometer sus horribles crímenes, frente a los que la sociedad está en principio atónita y después indefensa. Como dice la EM de la LO 13/2015, de 5 de octubre: "Los flujos de información generados por los sistemas de comunicación telemática advierten de las posibilidades que se hallan al alcance del delincuente, pero también proporcionan poderosas herramientas de investigación a los poderes públicos". Se trata por tanto de utilizar las mismas herramientas, las que proporciona la alta tecnología de la que disfrutamos en la actualidad, para luchar eficazmente contra esa delincuencia, casi siempre organizada.

Así mismo, en segundo lugar, algunos de los nuevos actos de investigación tecnológicos representan un nivel de agresión en la esfera personal y privada del ciudadano sospechoso de haber cometido el delito tan alto, que parecen hacernos decir que un nuevo Estado marcadamente policial podría estar pergeñándose.

Ante este panorama, al Estado no le ha quedado más remedio, para luchar con eficacia contra la nueva delincuencia tecnológicamente avanzada, que ponerse a su altura con los mismos medios para contrarrestarla, aunque para conseguirlo tenga que afectar a la vida privada de las personas. El problema es que al criminal le da igual vulnerar derechos constitucionales de los ciudadanos, pero al Estado democrático ello no le puede ser indiferente. Y aquí precisamente es donde se encuentra el principal problema de las medidas que vamos a estudiar a continuación. 
No debemos exagerar, pero tampoco dejar de estar atentos, pues el garantismo procesal en España ha alcanzado una cota una vez restablecida la democracia, tras décadas de ausencia, que vale la pena mantener en favor del juicio "justo" o con todas las garantías, siendo admisibles matices en donde ese nivel presente fisuras, justificadas bajo estrictos requisitos, que puedan afectar a derechos de la ciudadanía honesta. Es cierto que todos los países democráticos están reaccionando de la misma manera y todos tienen en alguna forma como actos de investigación los que ahora se han incorporado a la legislación española (USA, Alemania, Italia, España). La lucha contra la criminalidad organizada (definida por el art. 570 bis.1, II CP español) y los horribles crímenes que comete parecen justificar este nivel superior de control policial y judicial que estos actos representan.

Además, en tercer lugar, la cuestión jurídica se centra por tanto en hallar el equilibrio exacto entre la exigencia de tutelas específicas por la sociedad en peligro y los derechos del ciudadano imputado o sospechoso de haber cometido un crimen de esa naturaleza, siempre inocente hasta la sentencia de condena. Es la propia LO 13/2015 la que proporciona lo que a su juicio son instrumentos esenciales de ese equilibrio, a saber, el reconocimiento de unos principios rectores y la exigencia de cumplimiento de unos requisitos garantistas, que reafirmen a un tiempo el Estado de Derecho y la eficacia de la persecución de esos delitos. Sobre su regulación destacaré:

\section{Principios rectores y las garantías constitucionales y ordinarias de los nuevos actos de investigación tecnológicos.}

La Ley establece unas disposiciones comunes a los modernos actos de investigación tecnológicos [(arts. 588 bis a) a 588 bis k)], a los que llama principios rectores y garantías constitucionales y ordinarias de los nuevos actos de investigación tecnológicos. Se trata de los siguientes principios:

\section{De naturaleza constitucional.}

Exclusividad jurisdiccional. El acto de investigación únicamente se puede practicar si se ha autorizado previamente por el juez instructor mediante auto. En este sentido, la ley dispone que durante la instrucción de las causas se podrá acordar alguna de las medidas de investigación reguladas en el presente capítulo siempre que medie autorización judicial dictada con plena sujeción a los principios de especialidad, idoneidad, excepcionalidad, necesidad y proporcionalidad de la medida. El principio de idoneidad servirá para definir el ámbito objetivo y subjetivo y la duración de la medida en virtud de su utilidad.

La LECRIM regula con detalle el requisito de la autorización judicial, por ser sin duda el más importante y el que permite el control de los demás presupuestos. Lo importante es destacar que la policía judicial puede solicitar la medida, si bien lo usual es que lo haga el ministerio fiscal. También está legitimada para solicitar su prórroga. La resolución judicial que autorice la medida concretará, entre otros extremos, la unidad investigadora de policía judicial que se hará cargo de la intervención, quien estará obligada a informar al juez de instrucción del desarrollo y los resultados 
de la medida, en la forma y con la periodicidad que éste determine y, en todo caso, cuando por cualquier causa se ponga fin a la misma.

Investigación de un delito iniciada (principio de especialidad). El principio de especialidad exige que una medida esté relacionada con la investigación de un delito concreto. No podrán autorizarse medidas de investigación tecnológica que tengan por objeto prevenir o descubrir delitos o despejar sospechas sin base objetiva. Con ello se quieren prohibir expresamente las diligencias con carácter prospectivo, es decir, las que sin relación con un caso concreto se adoptan para buscar pruebas por si acaso hubiera algo (una diligencia de "peinado" por ejemplo).

Necesidad del acto de investigación. Es decir, en aplicación de los principios de excepcionalidad, idoneidad y especialidad solo podrá acordarse la medida:

Principio de proporcionalidad. Las medidas de investigación reguladas en este capítulo solo se reputarán proporcionadas cuando, tomadas en consideración todas las circunstancias del caso, el sacrificio de los derechos e intereses afectados no sea superior al beneficio que de su adopción resulte para el interés público y de terceros. Para la ponderación de los intereses en conflicto, la valoración del interés público se basará en la gravedad del hecho, su trascendencia social o el ámbito tecnológico de producción, la intensidad de los indicios existentes y la relevancia del resultado perseguido con la restricción del derecho.

Obsérvese, por tanto, que los únicos criterios para decidir si estamos ante una medida proporcionada ya no son la gravedad del hecho ni la trascendencia social del mismo, sino que se aumentan y adaptan mejor a la realidad. La concurrencia de los principios de exclusividad jurisdiccional, idoneidad, especialidad, necesidad y proporcionalidad, hace que la medida a adoptar sea legítima desde el punto de vista constitucional. Y no menos importante, el respeto a los mismos garantiza que tanto la medida como los resultados obtenidos serán prueba válida y lícita a efectos de la acusación o la defensa.

Duración. El plazo de vigencia de la medida no podrá exceder del tiempo imprescindible para el esclarecimiento de los hechos, aunque la ley española fija para cada acto un período concreto.

\section{De naturaleza ordinaria.}

Secreto. La solicitud y las actuaciones posteriores relativas a la medida solicitada se sustanciarán en una pieza separada y secreta, sin necesidad de que se acuerde expresamente el secreto de la causa (art. 588 bis d). Algo obvio, porque si el interceptado sabe que le están grabando no dirá nunca nada que tenga relevancia penal en su contra.

Extensión a terceros. Podrán acordarse las medidas de investigación reguladas en los siguientes capítulos aun cuando afecten a terceras personas en los casos y con las condiciones que se regulan en las disposiciones específicas de cada una de ellas. 
Esto significa, por poner un ejemplo concreto, que la diligencia de investigación de interceptación no busca intervenir el teléfono del titular o propietario solo, sino también el de cualquier usuario que sea un tercero procesal en estos momentos. Lo importante por tanto es el teléfono o medio de comunicación.

Utilización de la información obtenida en un procedimiento distinto y descubrimientos casuales. El uso de las informaciones obtenidas en un procedimiento distinto y los descubrimientos casuales es posible con arreglo a lo dispuesto en el artículo 579 bis (art. 588 bis i).

Cese de la medida. El art. Artículo 588 bis j) dispone que el juez acordará el cese de la medida cuando desaparezcan las circunstancias que justificaron su adopción o resulte evidente que a través de la misma no se están obteniendo los resultados pretendidos, y, en todo caso, cuando haya transcurrido el plazo para el que hubiera sido autorizada.

\section{Principios referentes a los actos concretos de investigación que implican el uso de alta tecnología.}

En cuanto a este tipo de actos destaco los siguientes:

\section{La intervención de las comunicaciones telefónicas y telemáticas.}

La antigüedad de la LECRIM impidió que se previera y regulara la posibilidad de tomar conocimiento, para los fines del proceso penal, de comunicaciones privadas que se efectúan a través de medios distintos al correo y telégrafo, como el teléfono, el télex, el fax, el correo electrónico y cualquier forma de mensajería instantánea a través de la red (Skype, FaceTime, Viber, Twitter, Facebook, SMS, MMS, WhatsApp, Messenger, Telegram, etc.).

Que el juez de instrucción pudiese intervenir una conversación telefónica o comunicación por télex, fax, o cualquier otro medio, era indudable ya desde el art. 18.3 CE, pero para actualizar la LECRIM se modificó su art. 579 en 1988, regulándose la intervención y escucha de conversaciones telefónicas en la fase de investigación del proceso penal. Pero en el fondo la reforma fue muy defectuosa, ya que el supuesto normativo resultó poco preciso y con evidentes lagunas, que han tenido que ir interpretándose y perfeccionándose progresivamente por la doctrina del TC (S 184/2003, de 23 de octubre), y por el TS, cuyo punto de partida es el Auto TS de 18 de junio de 1992 (RA 6102).

La reforma de la LECRIM ha venido también impuesta por el Tribunal Europeo de Derechos Humanos, que en diversos casos en los que se alegó la vulneración del art. 8 del Convenio (sobre todo Kruslin c. Francia, Huvig c. Francia, ambos de 1990, y Valenzuela Contreras c. España, de 1998), concluyó que era necesario que la limitación del derecho fundamental estuviera expresamente prevista por la ley y precisamente por una ley que fuera compatible con la preeminencia del derecho. En esta doctrina ha insistido la STEDH de 18 de febrero de 2003 (caso Prado Bugallo). 
Ante estos antecedentes, la LO 13/2015, ha procedido a reformar profundamente el acto de investigación meritado, que pasa a denominarse "Interceptación de las comunicaciones telefónicas y telemáticas", regulado en el nuevo Capítulo V del Título VIII del Libro II LECRIM, arts. 588 ter a) a 588 ter m). Se trata de un desarrollo específico y muy relevante en el ámbito del proceso penal del derecho al secreto de las comunicaciones consagrado en el art. 18.3 de la Constitución. La medida afecta a todos los medios de comunicación posibles a través del teléfono o telemáticamente (tanto los conocidos hoy como los que en el futuro puedan incorporarse al mercado). Como puede suponerse fácilmente, todos los ciudadanos, en calidad de usuarios, somos susceptibles de ella ante la utilización masiva de los mismos.

Por interceptación debe entenderse tomar conocimiento la autoridad judicial o la policial por su delegación de comunicaciones telefónicas (verbales), en cualquiera de los medios posibles, o telemáticas (escritas), igualmente sea cual fuere el programa utilizado, mediante el uso de aparatos configurados técnicamente para ello, entre dos o más personas que desconocen la interceptación y que se encuentran separadas entre sí.

Antes de la aprobación de la reforma operada por la LO 13/2015, ya el TS había tenido ocasión de pronunciarse sobre la utilización como prueba de conversaciones usando redes sociales (como Twitter, Facebook, Twenti, etc.) o la utilización de mensajes mediante el medio más utilizado en España, el WhatsApp, admitiendo su validez con cautela y dados ciertos requisitos, tanto mediante aportación directa de los mismos como mediante la llamada coloquialmente técnica del "pantallazo" o foto de pantalla que se incorpora como documento gráfico (SS núm. 850 / 2014, de 26 de noviembre [RJ 2014 \6423]; y núm. 300 / 2015, de 19 de mayo, RJ 2015 \1920). Referencia importante también fue la doctrina de inconstitucionalidad de las grabaciones de conversaciones del detenido en sede policial mientras no se reformara profundamente el art. 579 LECRIM, pues con su hoy derogada redacción no daba cobertura legal a las mismas (S TC 145/2014, de 22 de septiembre).

La limitación del derecho formal al secreto de la comunicación exige la concurrencia de unos requisitos, que pueden clasificarse en constitucionales y de legalidad ordinaria, produciendo esta distinción importantes consecuencias.

Requisitos constitucionales. Son los indicados anteriormente, con alguna precisión. La importancia de atribuir a un requisito naturaleza constitucional radica en que el desconocimiento del mismo supone la aplicación del art. 11.1 de la LOPJ, con lo que no surtirán efecto las pruebas obtenidas, directa o indirectamente, vulnerando el derecho del art. 18.3 CE, además de abrirse la posibilidad del amparo constitucional.

Un problema importante que se puede plantear es que, en caso de urgencia, cuando las investigaciones se realicen para la averiguación de delitos relacionados con la actuación de bandas armadas o elementos terroristas y existan razones fundadas que hagan imprescindible la medida prevista en los apartados anteriores de este artículo, podrá ordenarla el ministro del interior o, en su defecto, el secretario de estado de seguridad. Quien la va a ejecutar es por tanto la policía, pero no la judicial, sino la administrativa. 
Esta medida se comunicará inmediatamente al juez competente y, en todo caso, dentro del plazo máximo de veinticuatro horas, haciendo constar las razones que justificaron la adopción de la medida, la actuación realizada, la forma en que se ha efectuado y su resultado. El juez competente, también de forma motivada, revocará o confirmará tal actuación en un plazo máximo de setenta y dos horas desde que fue ordenada la medida.

La labor de la policía judicial, coordinadamente con el prestador del servicio de telecomunicaciones es clave para el éxito de la investigación. La policía es quien escucha y transcribe las conversaciones, aportando al juez aquella parte que afecte a la investigación en curso, aunque éste siempre le puede solicitar el contenido íntegro de las conversaciones intervenidas.

La ley impone un deber de colaboración con el juez, el fiscal y la policía a todos los prestadores de servicios de telecomunicaciones, de acceso a una red de telecomunicaciones o de servicios de la sociedad de la información, así como a toda persona que de cualquier modo contribuya a facilitar las comunicaciones a través del teléfono o de cualquier otro medio o sistema de comunicación telemática, lógica o virtual, bajo secreto, para que este acto de investigación se pueda practicar, pudiendo incurrir en delito de desobediencia en caso contrario (art. 588 ter e).

Debo referirme al principio de prohibición del exceso, pues se exige: En primer lugar, necesidad de la medida. Ella supone que la intervención telefónica tiene que ser el único medio por el que puede descubrirse la existencia del delito o de sus circunstancias o, por lo menos, el medio por el que se sacrifican menos los derechos fundamentales del imputado (recordemos que es un principio rector, fijado en el art. 588 bis a)-5). En último caso la necesidad tiene que referirse a que los otros posibles medios de investigación de un determinado delito y de una concreta persona no ofrecen garantías de alcanzar la finalidad perseguida. Por ello es por lo que a veces se habla, no de necesidad, sino de subsidiariedad.

En segundo lugar, proporcionalidad de la misma. El principio viene fijado ahora por el nuevo art. 588 ter a), al disponer que la autorización para la interceptación de las comunicaciones telefónicas y telemáticas solo podrá ser concedida cuando la investigación tenga por objeto alguno de los delitos a que se refiere el artículo 579.1 de esta ley o delitos cometidos a través de instrumentos informáticos o de cualquier otra tecnología de la información o la comunicación o servicio de comunicación. Recordemos que esos delitos son los siguientes: 1 . $^{\circ}$ delitos dolosos castigados con pena con límite máximo de, al menos, tres años de prisión. 2. ${ }^{\circ}$ delitos cometidos en el seno de un grupo u organización criminal. 3. ${ }^{\circ}$ delitos de terrorismo.

Por tanto, se trata de los delitos graves y más graves, siguiendo la tendencia europea de no permitir la interceptación en cualquier caso. Se acaba así con la perturbadora idea de permitir la medida, como ocurría hasta ahora con fundamento jurisprudencial, con base en la naturaleza del delito, tanto por lo que se refería a la pena del mismo, como a su trascendencia social (v. SS TC 166/1999, de 27 de septiembre; y 167 / 2002, de 18 de septiembre). Ahora el criterio es puramente objetivo, 
salvo para los delitos dolosos, en los que se opta por el valor cuantitativo de la pena (tres años de prisión), lo que permite que muchos delitos menos graves caigan dentro del requisito.

La cuestión más grave que se presenta en la práctica es la del descubrimiento de hechos casuales o "descubrimiento inevitable", esto es, el que al estar investigando un delito y a una persona determinada, se intervenga una conversación por la que se conoce otro delito con autor diferente. La solución jurisprudencial no era clara, pero se admitía que el juez podía inmediatamente, por medio de auto, bien ampliar el objeto de la investigación en el mismo procedimiento preliminar, bien proceder a incoar nuevo procedimiento. La adquisición de resultados de investigación mediante pruebas ilícitas o ilegalmente obtenidas, que de otra manera lícita o legal se habrían obtenido necesariamente, es constitucionalmente válida según nuestra jurisprudencia (STS de ocho de febrero de 2000, RA 291), pero esta doctrina debe ser analizada con sumo cuidado por los evidentes peligros que entraña a la vista del nuevo art. 588 bis i), párrafo II, en relación con el art. 579 bis LECRIM.

Requisitos de legalidad ordinaria. Me fijaré tan solo en el llamado control judicial. La exclusividad jurisdiccional supone que la medida es decretada solo por el juez de instrucción y que al mismo corresponde la ejecución de la misma. Razones prácticas, con todo, aconsejan que la actividad física de la escucha y de la grabación se encomiende a la policía judicial, si bien debe tenerse en cuenta que ésta actúa en todo caso bajo las órdenes directas del juez. Consiguientemente no se trata de que el Juez «controle» a la policía en una actividad propia de ésta, sino de que aquél se auxilie de ésta (v. S TC 9/2011, de 28 de febrero). Ese auxilio supone, entre otras cosas, que el juez debe dar las instrucciones necesarias sobre cómo se realiza la intervención.

El art. 588 ter f) establece por ello que la policía judicial pondrá a disposición del juez, con la periodicidad que éste determine y en soportes digitales distintos, la transcripción de los pasajes que considere de interés y las grabaciones íntegras realizadas. Se indicará el origen y destino de cada una de ellas y se asegurará, mediante un sistema de sellado o firma electrónica avanzado o sistema de adveración suficientemente fiable, la autenticidad e integridad de la información volcada desde el ordenador central a los soportes digitales en que las comunicaciones hubieran sido grabadas.

\section{La captación y grabación de comunicaciones orales mediante la utilización de dispositivos electrónicos.}

El nuevo Capítulo VI del Título VIII del Libro II regula la "Captación y grabación de comunicaciones orales mediante la utilización de dispositivos electrónicos", arts. 588 quater a), a 588 quater e) LECRIM. En realidad, va más allá, pues también permite la captación de imágenes. Constituye igualmente un desarrollo específico en el ámbito del proceso penal del derecho al secreto de las comunicaciones del art. 18.3, pero no solo, pues también está afectado el derecho a la inviolabilidad del domicilio del art. 18.2 y del derecho a la privacidad (intimidad y propia imagen) del art. 18.1 de la Constitución. La razón para introducir esta medida se funda en la experiencia que ha proporcionado la persecución de determinados delitos hasta ahora, en los que 
captar lo que están hablando dos personas en un lugar público o abierto con medios técnicos resulta imprescindible para su esclarecimiento.

Como hay un evidente peligro de extralimitación, la LECRIM limita la procedencia del acto de investigación a encuentros concretos que vaya a mantener el investigado, debiéndose identificar con precisión el lugar o dependencias sometidos a vigilancia. En otras palabras, no se legitiman autorizaciones de captación y grabación de conversaciones orales con carácter general o indiscriminado.

Es posible la grabación de las comunicaciones orales directas en los siguientes términos: Podrá autorizarse la colocación y utilización de dispositivos electrónicos que permitan la captación y grabación de las comunicaciones orales directas que se mantengan por el investigado, en la vía pública o en otro espacio abierto, en su domicilio o en cualesquiera otros lugares cerrados. Los dispositivos de escucha y grabación podrán ser colocados tanto en el exterior como en el interior del domicilio o lugar cerrado. Pero si fuese necesaria la entrada en el domicilio o en alguno de los espacios destinados al ejercicio de la privacidad para la instalación de los correspondientes dispositivos, la resolución habilitante habrá de extender su motivación a la procedencia del acceso a dichos lugares.

Adicionalmente, la escucha y grabación de las conversaciones privadas se podrá complementar con la obtención de imágenes cuando expresamente lo autorice la resolución judicial que la acuerde. Obsérvese que no se regula la grabación entre particulares (v. gr., con cámara oculta), por lo que habrá que estar a la S TS núm. 793/2013, de 28 de octubre, que en principio admite su validez. Con ello queda afectado no solo el investigado sino también todo su entorno familiar.

Solo podrá autorizarse cuando concurran los requisitos siguientes: de un lado, que los hechos que estén siendo investigados sean constitutivos de alguno de los siguientes delitos: $1 .^{\circ}$ delitos dolosos castigados con pena con límite máximo de, al menos, tres años de prisión. 2. ${ }^{\circ}$ delitos cometidos en el seno de un grupo u organización criminal. 3. ${ }^{\circ}$ delitos de terrorismo. $Y$, del otro, que pueda racionalmente preverse que la utilización de los dispositivos aportará datos esenciales y de relevancia probatoria para el esclarecimiento de los hechos y la identificación de su autor.

La policía judicial pondrá a disposición de la autoridad judicial el soporte original o copia electrónica auténtica de las grabaciones e imágenes, que deberá ir acompañado de una transcripción de las conversaciones que considere de interés. El informe identificará a todos los agentes que hayan participado en la ejecución y seguimiento de la medida (art. 588 quater d).

\section{La utilización de dispositivos técnicos de captación de la imagen, de seguimiento y de localización.}

El nuevo Capítulo VII del Título VIII del Libro II LECRIM regula la “Utilización de dispositivos técnicos de captación de la imagen, de seguimiento y de localización”, arts. 588 quinquies a) a art. 588 quinquies c). Puesto que se trata de un acto de 
investigación a practicar en lugares públicos, debe ser puesto en relación con el acto de filmación en lugares públicos (v. infra). Constituye igualmente otro desarrollo específico en el ámbito del proceso penal del derecho al secreto de las comunicaciones del art. 18.3 de la Constitución, pero también queda afectado el derecho a la privacidad (intimidad y propia imagen) del art. 18.1 de la Constitución.

La captación de imágenes en lugares o espacios públicos (estamos hablando por ejemplo del sistema de geolocalización de posicionamiento global o GPS) queda sujeta a los requisitos establecidos en el art. 588 quinquies a): La policía judicial podrá obtener y grabar por cualquier medio técnico imágenes de la persona investigada cuando se encuentre en un lugar o espacio público, si ello fuera necesario para facilitar su identificación, para localizar los instrumentos o efectos del delito u obtener datos relevantes para el esclarecimiento de los hechos. La medida podrá ser llevada a cabo aun cuando afecte a personas diferentes del investigado, siempre que de otro modo se reduzca de forma relevante la utilidad de la vigilancia o existan indicios fundados de la relación de dichas personas con el investigado y los hechos objeto de la investigación.

Al amparo de este acto de investigación, vulnera el derecho constitucional a la inviolabilidad del domicilio y el derecho constitucional a la intimidad la utilización de prismáticos, que ciertamente no graban imágenes, por la policía desde un lugar público para observar lo que ocurre en un domicilio, aunque las ventanas estén abiertas o las cortinas despasadas; al igual que el uso de drones con la misma finalidad de intrusión virtual. En ambos casos, a falta del consentimiento del interesado, se requiere autorización judicial expresa (v. S TS núm. 329/2016, de 20 de abril, RJ 2016 \1691, FD 2). Los prestadores, agentes y personas a que se refiere el artículo 588 ter e) están obligados a facilitar al juez, al ministerio fiscal y a los agentes de la policía judicial designados para la práctica de la medida la asistencia y colaboración precisas para facilitar el cumplimiento de los autos por los que se ordene el seguimiento, bajo apercibimiento de incurrir en delito de desobediencia.

Cuando concurran razones de urgencia que hagan temer razonablemente que, de no colocarse inmediatamente el dispositivo o medio técnico de seguimiento y localización, se frustrará la investigación, la policía judicial podrá proceder a su colocación, dando cuenta a la mayor brevedad posible, y en todo caso en el plazo máximo de veinticuatro horas, a la autoridad judicial, quien podrá ratificar la medida adoptada o acordar su inmediato cese en el mismo plazo. En este último supuesto, la información obtenida a partir del dispositivo colocado carecerá de efectos en el proceso.

La policía judicial entregará al juez los soportes originales o copias electrónicas auténticas que contengan la información recogida cuando éste se lo solicite y, en todo caso, cuando terminen las investigaciones. La información obtenida a través de los dispositivos técnicos de seguimiento y localización a los que se refieren los artículos anteriores deberá ser debidamente custodiada para evitar su utilización indebida. 


\section{El registro de dispositivos de almacenamiento masivo de información.}

El nuevo Capítulo VIII del Título VIII del Libro II LECRIM regula el "Registro de dispositivos de almacenamiento masivo de información", arts. 588 sexies a) a art. 588 sexies c). Estamos ante otro desarrollo específico en el ámbito del proceso penal del derecho al secreto de las comunicaciones del art. 18.3 de la Constitución. También quedan afectados indiscutiblemente el derecho a la protección de datos del art. 18.4 y el derecho a la privacidad (intimidad y propia imagen) del art. 18.1 de la Constitución. Ante esta complejidad dogmática se habla modernamente del "derecho al propio entorno virtual" (S TS núm. 342/2013, de 17 de abril [RJ 2013 \3296]), como derecho de nueva generación integrador de todos los citados en estos supuestos. Se cubre un vacío legal importante con la aprobación de este acto de investigación. Para la EM de la LO 13/2015, esta reforma descarta cualquier duda acerca de que esos instrumentos de comunicación y, en su caso, almacenamiento de información son algo más que simples piezas de convicción. De ahí que se haya fijado una exigente regulación respecto del acceso a su contenido.

Se evitará la incautación de los soportes físicos que contengan los datos o archivos informáticos, cuando ello pueda causar un grave perjuicio a su titular o propietario y sea posible la obtención de una copia de ellos en condiciones que garanticen la autenticidad e integridad de los datos. Cuando quienes lleven a cabo el registro o tengan acceso al sistema de información o a una parte del mismo conforme a lo dispuesto en este capítulo, tengan razones fundadas para considerar que los datos buscados están almacenados en otro sistema informático o en una parte de él, podrán ampliar el registro, siempre que los datos sean lícitamente accesibles por medio del sistema inicial o estén disponibles para éste. Esta ampliación del registro deberá ser autorizada por el juez, salvo que ya lo hubiera sido en la autorización inicial. En caso de urgencia, la policía judicial o el fiscal podrán llevarlo a cabo, informando al juez inmediatamente, y en todo caso dentro del plazo máximo de veinticuatro horas, de la actuación realizada, la forma en que se ha efectuado y su resultado. El Juez competente, también de forma motivada, revocará o confirmará tal actuación en un plazo máximo de setenta y dos horas desde que fue ordenada la interceptación.

En los casos de urgencia en que se aprecie un interés constitucional legítimo que haga imprescindible la medida prevista en los apartados anteriores de este artículo, la policía judicial podrá llevar a cabo el examen directo de los datos contenidos en el dispositivo incautado, comunicándolo inmediatamente, y en todo caso dentro del plazo máximo de veinticuatro horas, por escrito motivado al Juez competente, haciendo constar las razones que justificaron la adopción de la medida, la actuación realizada, la forma en que se ha efectuado y su resultado. El juez competente, también de forma motivada, revocará o confirmará tal actuación en un plazo máximo de 72 horas desde que fue ordenada la medida. Las autoridades y agentes encargados de la investigación podrán ordenar a cualquier persona que conozca el funcionamiento del sistema informático o las medidas aplicadas para proteger los datos informáticos contenidos en el mismo que facilite la información que resulte necesaria, 
siempre que de ello no derive una carga desproporcionada para el afectado, bajo apercibimiento de incurrir en delito de desobediencia.

\section{Los registros remotos sobre equipos informáticos.}

El también nuevo Capítulo IX del Título VIII del Libro II regula los "Registros remotos sobre equipos informáticos", arts. 588 septies a), a 588 septies c) LECRIM. Es la última de las medidas de investigación tecnológica introducidas en 2015 fundada en el art. 18.3 de la Constitución, sin perjuicio de poder quedar afectados también el derecho a la protección de datos del art. 18.4 y el derecho a la privacidad (intimidad y propia imagen) del art. 18.1 de la Constitución.

Con la aprobación de este acto de investigación se cubre otro vacío legal importante, adaptando nuestra legislación a las más avanzadas en Europa. Se trata de utilizar programas informáticos (software) altamente sofisticados que se introducen desde centros de control policial en el ordenador u ordenadores estáticos o portátiles (laptop), tabletas, teléfonos móviles, etc., en cuanto aparatos que almacenan datos del investigado, con el fin de extraer cualquier tipo de información que en él se contenga válida a efectos de investigación de un crimen.

Se comprende inmediatamente que estamos ante una medida altamente agresiva, puesto que utilizar la llamada técnica del "gusano informático" para espiar ordenadores ajenos, es en el fondo tener acceso a toda la vida virtual del investigado, quien ciertamente se ampara en el anonimato que proporciona Internet para cometer sus crímenes, por lo que habrá que estar muy atentos a las prevenciones que hicimos al comienzo de esta lección. Por eso el legislador quiere reforzar el ámbito objetivo de la medida, para lo que se han acotado con un listado numerus clausus los delitos que la pueden habilitar, y limitar la duración temporal, lo que en estos momentos no sabemos aún si será suficiente. Procede si se persigue la investigación de alguno de los siguientes delitos: a) delitos cometidos en el seno de organizaciones criminales. b) delitos de terrorismo. c) delitos cometidos contra menores o personas con capacidad modificada judicialmente. d) delitos contra la Constitución, de traición y relativos a la defensa nacional. e) delitos cometidos a través de instrumentos informáticos o de cualquier otra tecnología de la información o la telecomunicación o servicio de comunicación.

Obsérvese que la ley, una vez autorizado el acceso al dispositivo de almacenamiento de datos, por ejemplo, al ordenador estático que tiene en su casa el investigado, permite rastrear cualquier elemento del sistema, cualquier programa, cualquier dato, cualquier base de datos, cualquier texto, etc., contenido en él. Todo es por tanto objeto de investigación. Sorprende por ello que se incluyan muchos delitos que ni siquiera podrían llegar a ser menos graves, a la vista del tenor literal de los apartado c) y e) del precepto. Sería de desear por el principio de proporcionalidad una mayor precisión de esos delitos.

Cuando los agentes que lleven a cabo el registro remoto tengan razones para creer que los datos buscados están almacenados en otro sistema informático o en una par- 
te del mismo, pondrán este hecho en conocimiento del juez, quien podrá autorizar una ampliación de los términos del registro. Se obliga a colaborar con la justicia a los prestadores de servicios y personas señaladas en el artículo 588 ter e), y a los titulares o responsables del sistema informático o base de datos objeto del registro, para la práctica de la medida y el acceso al sistema. Asimismo, están obligados a facilitar la asistencia necesaria para que los datos e información recogidos puedan ser objeto de examen y visualización. Las autoridades y los agentes encargados de la investigación podrán ordenar a cualquier persona que conozca el funcionamiento del sistema informático o las medidas aplicadas para proteger los datos informáticos contenidos en el mismo que facilite la información que resulte necesaria para el buen fin de la diligencia. Deben guardar secreto y están sujetos a responsabilidad.

\section{Algunos aspectos complejos de la actuación policial en calidad de autoridad pública de persecución del delito en los momentos actuales}

Como es fácilmente imaginable a la vista de lo expuesto hasta aquí, la policía judicial como autoridad pública de persecución del crimen, realiza numerosas actuaciones y de muy distinto contenido. No es de extrañar por ello que en la práctica se destaquen algunas de ellas que, junto con las que infringen los derechos fundamentales del investigado, antes analizadas, son especialmente problemáticas o presentan problemas jurídicos de enjundia. Antes he recogido algunos actos de investigación garantizados en los que la actuación de la policía judicial es clave para el éxito de esta fase procesal. Trataré aquí las diligencias de prevención, el atestado policial, las declaraciones del investigado y el valor jurídico de las actuaciones policiales.

\section{Diligencias de prevención.}

Son de una importancia decisiva, porque implican las primeras actuaciones tras el descubrimiento del crimen. Son las siguientes: Dar protección a los ofendidos y perjudicados por el delito, a sus familiares o a otras personas, consignar las pruebas del mismo que puedan desaparecer, recoger y poner en custodia cuanto conduzca a su comprobación y a la identificación del delincuente, y detener en su caso a los sospechosos (art. 13 LECRIM).

La ejecución de las primeras diligencias significa, en ciertos casos de gran trascendencia social y que requieren una actuación urgente, la adopción de determinadas medidas cautelares, no solo penales, pues también pueden tener naturaleza civil. Eso sucede con la protección procesal penal de las víctimas de la violencia de género, pudiéndose decretar en concreto las previstas en el art. 544 bis, o en el art. 544 ter. Es importante resaltar que su competencia es exclusivamente judicial, por tanto, en ningún caso puede la policía judicial proceder a su imposición. La práctica de estas diligencias obliga a comunicar la comisión del delito a la autoridad judicial o fiscal inmediatamente, salvo que se perjudique la propia investigación (arts. 284 y 295 LECRIM, éste último modificado parcialmente por la Ley 41/2015, de 5 de octubre).

Téngase en cuenta que el aseguramiento (detención) del presunto autor de los hechos, y el auxilio a las víctimas del delito, son diligencias prioritarias para la Ley, 
de manera que únicamente pueden practicarse otras cuando estas dos, en su caso, estén cumplidas (art. 366 LECRIM). Sobre la práctica en concreto de las diligencias, conviene tener en cuenta los siguientes aspectos: En primer lugar, la obligación de practicar las diligencias de prevención surge para la policía judicial en el momento tengan noticia de la comisión de un hecho punible (art. 4 RD 769/1987, de 19 de junio). En segundo lugar, la práctica de las diligencias de prevención cesa cuando se haga cargo de la investigación la autoridad judicial, o el fiscal encargado de las actuaciones, a quienes se hará entrega de todo lo practicado, incluyendo los efectos intervenidos, poniendo a su disposición las personas detenidas si las hubiere (art. 5 Real Decreto 769/1987, de 19 de junio);

Y, en tercer lugar, algo muy importante: No habiéndose incoado sumario o diligencias previas, en los países en los que como en España existe la figura del juez instructor, el jefe de los miembros de la policía judicial es exclusivamente el fiscal, por lo que solo a él deben dar cuenta de las investigaciones practicadas, sin perjuicio de ejecutar las que les ordene (art. 20 RD 769/1987, de 19 de junio).

Tratándose de diligencias de prevención practicadas por la Policía Local, esta función, necesaria tras la presentación de las correspondientes denuncias por los ciudadanos por hechos delictivos, o por conocimiento propio, consiste en realizar las diligencias que el caso aconseje y que tengan carácter urgente, $\mathrm{y}$, tanto si se han completado como si no, dar parte inmediatamente a la Comisaría del Cuerpo Nacional de Policía o al puesto de la Guardia Civil autorizado más cercano. En caso de que se haya practicado una detención, deberá entregar la Policía Local al detenido inmediatamente a la Policía Nacional o a la Guardia Civil.

Finalmente, qué tipo de diligencias pueden practicarse. La respuesta es muy sencilla, puesto que, dado que el acto de investigación a realizar depende fundamentalmente del hecho delictivo concreto producido, y dado que el art. 13 LECRIM establece las diligencias con carácter abierto, se pueden ejecutar todas las conducentes al buen fin de la investigación (v. art. 299 LECRIM), salvo que su autorización esté reservada exclusivamente al juez o al fiscal. No obstante, la ley clasifica las actuaciones, sin perjuicio de que para el proceso abreviado y para el proceso especial para el enjuiciamiento rápido de determinados delitos los arts. 770 y 796 establezcan disposiciones específicas, en cinco grupos, cuyo orden seguimos:

- Dar protección a los perjudicados: No solo está pensando el legislador en posibles consejos jurídicos a la víctima del delito, sino y más fundamental en realizar las actuaciones físicas que permitan a ésta hacer que la situación se recupere, cese o quede protegida frente al peligro del delito. Por ejemplo, llevarla a un hospital, recoger sus pertenencias, evitar la continuación de la agresión, etc. La protección comprende también a los familiares de los ofendidos o perjudicados e, incluso, a otras personas.

- Consignar las pruebas del delito que puedan desaparecer: Actuación totalmente necesaria, puesto que la prueba va a servir para convencer al juez el día del juicio oral si el acusado es culpable o inocente (art. 741, I, LECRIM). 
Su pérdida podría significar sin duda el fracaso del proceso y la impunidad del delincuente. Así, el miembro de la policía judicial deberá anotar todos los testigos que hayan presenciado el hecho, los elementos que requieran una actuación posterior de carácter pericial, etc.

- Recoger y poner en custodia cuanto conduzca a la comprobación del delito (piezas de convicción): Los miembros de la policía judicial deben asegurar también aquellos objetos que sean las piezas de convicción del delito, como el arma homicida, la droga, los documentos contables, etc., que sirven para que el órgano jurisdiccional se forme una idea exacta de cómo han ocurrido los hechos (arts. 438 y 712 LECRIM).

- Identificación del delincuente: Si no es posible directamente, leyendo su documentación personal, las actuaciones a practicar permiten incluir la toma de huellas dactilares, descripción de testigos, etc.

- Detener al presunto autor: Posibilidad permitida con carácter general por el art. 492 LECRIM, que es una medida cautelar personal.

\section{Atestado policial.}

La gran especialización técnica de la policía judicial actual, que la ha convertido realmente en una policía científica, hace que sus actuaciones tengan un contenido muy rico desde el punto de vista procesal, tanto que su valor, a efectos sobre todo probatorios, puede ser decisivo en la fundamentación de las sentencias de condena. No siendo sin embargo ni autoridad judicial ni fiscal, la LECRIM, anticuada en este tema, no ha previsto que la documentación policial relativa a actos de investigación penal, que hoy es ciertamente compleja, tiene diferente valor y alcance. De ahí que la jurisprudencia, tanto la del TS como la del TC, hayan precisado, sobre todo últimamente, estas cuestiones.

El atestado policial es el documento que contiene la investigación (entendida como conjunto y no como unidad) realizada por la Policía respecto a un hecho aparentemente criminal, sea de la naturaleza que sea. En principio tiene valor de denuncia, según el art. 297, I, LECRIM, pero esta declaración legal es decir bien poco. Los atestados, por tanto, pueden tener muy diversos orígenes o fundamentos. Por eso la jurisprudencia ha precisado lo siguiente:

En primer lugar, el atestado tiene valor de denuncia, como hemos indicado, de manera que cumple la función de ser acto de iniciación del proceso penal (declaración que ha formulado el TC desde su Sentencia 31/1981, de 28 de julio, y ha reiterado luego constantemente).

Así mismo, en segundo lugar, para que el acto de iniciación pueda llegar a tener consecuencias probatorias es necesario que el miembro de la policía judicial que lo redactó declare como testigo en el juicio oral ante el tribunal juzgador y sentenciador, reiterándolo y ratificándolo. El policía es así en el proceso penal testigo (S TC 
173/1985, de 16 de diciembre; y SS TS de 10 de diciembre de 1986, RA 7873; y de 18 de enero de 1988, RA 300, entre otras muchas).

No se trata de que el atestado se convierta en medio de prueba en el juicio oral, sino de que los hechos constados en él pueden llegar a entrar en el juicio oral por medio de la declaración del policía como testigo, que es cosa muy diferente y por ese camino pueden llegar a tener consecuencias probatorias. Naturalmente esos hechos han de haber sido antes afirmados por las partes.

Además, en cuanto al contenido estricto de los atestados, la importantísima S TS de 23 de enero de 1987 (RA 450), ha hecho las siguientes distinciones:

La primera de ellas es que cuando se trata de opiniones o apreciaciones de la Policía (por ejemplo, su parecer de cómo han ocurrido los hechos), de las declaraciones de los imputados, aunque se les haya instruido de sus derechos constitucionales y hayan gozado de la asistencia de Abogado, de declaraciones de testigos, de diligencias de identificación o de reconocimiento, en rueda o fuera de ella, o de otras diligencias semejantes, efectivamente, no se les puede atribuir por sí solas otro valor que el de meras denuncias, aunque luego si el policía declara como testigo en el juicio oral debe estarse al valor probatorio de este medio de prueba;

La segunda es que cuando se trata de dictámenes o de informes emitidos por gabinetes de los que actualmente dispone la policía, tales como los de dactiloscopia, identificación, análisis químicos, balísticos y otros análogos, tendrán, al menos, valor de dictámenes periciales, aunque deban ser ratificados en presencia judicial, durante las sesiones del juicio oral y con la posibilidad de que las partes puedan dirigir observaciones u objeciones o pedir aclaraciones a los miembros de los referidos gabinetes; y,

Finalmente, la tercera es que tratándose de diligencias objetivas y de resultado incuestionable, como la aprehensión «in situ» de los delincuentes, los supuestos en que éstos sean sorprendidos en situación de flagrancia o de cuasi flagrancia, la ocupación y recuperación de los efectos e instrumentos del delito, armas, drogas o sustancias estupefacientes, efectos estancados o prohibidos, entrada y registro en lugar cerrado y lo que se hallara durante el transcurso de los mismos, siempre que mediara asentimiento del morador o del que tiene derecho a excluir, o de otros supuestos semejantes, el valor que debe atribuírsele es el de verdaderas pruebas (documentales o periciales, añadimos nosotros, sin perjuicio de la testifical del agente), sometidas como las demás al principio de libre valoración establecido en los arts. 717 y 741, I, LECRIM.

El art. 75 de la Ley de Tráfico de 1990, para los supuestos específicos en que intervengan los agentes con competencias en materia de circulación vial, añade que las denuncias efectuadas por los mismos harán fe, salvo prueba en contrario, respecto de los hechos denunciados, sin perjuicio del deber de aquéllos de aportar todos los elementos probatorios que sean posibles sobre el hecho denunciado. La jurisprudencia, sin embargo, con buen criterio, hace caso omiso de esta vinculación probatoria, 
porque conforme a los preceptos de la LECRIM acabados de citar, todas las pruebas, absolutamente todas, se valoran por los tribunales penales libremente.

\section{Declaraciones ante la Policía y su valor jurídico.}

La Jurisprudencia ha tenido ocasión igualmente de pronunciarse acerca del valor probatorio que tienen las declaraciones formuladas por los imputados ante la policía judicial, particularmente cuando luego no son ratificadas por estos en el acto del juicio, e incluso son negadas.

El principio general parte de la necesidad de practicar las diligencias de referencia rodeadas de todas las garantías establecidas por el art. 17 CE y la legislación ordinaria (art. 520 LECRIM fundamentalmente, precepto que ha sufrido dos modificaciones en el año 2015, la primera por la Ley Orgánica 5/2015, de 27 de abril, y la segunda, de mayor calado, por la Ley Orgánica 13/2015, de 5 de octubre), y en particular con la presencia del abogado defensor (S TC 31/1981, de 28 de julio).

Para que dichas declaraciones alcancen el valor de prueba tienen que ser ratificadas por el posteriormente acusado en el acto del juicio oral, y así poder el órgano jurisdiccional formar su convicción libremente, tanto en lo relativo a su ratificación en sentido estricto, como si el acusado niega o se contradice respecto a lo declarado ante la Policía o el propio juez de instrucción, ya que en este último caso el tribunal debe realizar una apreciación conjunta sobre todas las declaraciones producidas (doctrina sentada por el TC en sus SS 80 / 1986, de 17 de junio; y 217/1989, de 21 de diciembre, entre otras muchas).

La clave de esta interpretación se basa en que el acusado, de un lado, haya sido interrogado con respeto íntegro a todos sus derechos constitucionales y, en segundo lugar, que tenga oportunidad el día del juicio oral de explicar la rectificación o retractación de su declaración, naturalmente con vigencia del principio de contradicción (SS TC 161/1990, de 19 de octubre; y 80/1991, de 15 de abril).

No obstante, nos parece que siendo la única prueba realizada en el proceso, la retractación o negación en el acto del juicio de la declaración ante la policía no puede llevar más que a la absolución, puesto que solo el segundo acto es probatorio y nunca el primero, y conforme al art. 741, I, LECRIM la convicción judicial se forma con base en la actividad probatoria y no a la sumarial o policial, sin perjuicio de infringir el principio de la presunción de inocencia, al no existir mínima actividad probatoria de cargo, según la conocida doctrina del TC al respecto. No obstante, la revelación de datos ante la policía que únicamente puede conocer el imputado declarante, sí debería ser valorable como prueba aunque luego se retracte, si tal declaración fue hecha con todas las garantías que la ley prevé. Y, por supuesto, deberían ser igualmente valorables como prueba en lo que afecten a otros participantes, aunque luego se retracte.

Pero, en lo que se refiere a España, el último Acuerdo de la Sala II en Pleno no Jurisdiccional de 3 de junio de 2015, que deroga el Acuerdo de 28 de noviembre de 
2006, relativo al valor de la declaración del imputado en sede judicial, al haber perdido su validez como consecuencia de la STC 68/2010, de 18 de octubre, no admite ni una sola excepción. En su virtud: «Las declaraciones ante los funcionarios policiales no tienen valor probatorio. No pueden operar como corroboración de los medios de prueba. Ni ser contrastadas por la vía del art. 714 de la LECR. Ni cabe su utilización como prueba pre constituida en los términos del art. 730 de la LECR. Tampoco pueden ser incorporadas al acervo probatorio mediante la llamada como testigos de los agentes policiales que las recogieron. Sin embargo, cuando los datos objetivos contenidos en la autoinculpación son acreditados como veraces por verdaderos medios de prueba, el conocimiento de aquellos datos por el declarante evidenciado en la autoinculpación puede constituir un hecho base para legítimas y lógicas inferencias. Para constatar, a estos exclusivos efectos, la validez y el contenido de la declaración policial deberán prestar testimonio en el juicio los agentes policiales que la presenciaron. La condena vendría asegurada, por tanto, existiendo otras pruebas de cargo, coadyuvando como otro elemento más la valoración judicial de la retractación.

\section{Otras actuaciones problemáticas.}

\section{Intervenciones específicas de la policía judicial en materia de seguridad ciudadana.}

Sin entrar en muchos detalles, la Ley Orgánica 4/ 2015, de 30 de marzo, de Protección de la Seguridad ciudadana, prevé actuaciones administrativas que debe desarrollar la policía (administrativa) que pueden acabar siendo materia de proceso penal por transformarse o dar paso a un delito, en el que actuarán como policía judicial. Así, atendidos los arts. 15 (entrada y registro en domicilio y edificios de organismos oficiales), 16 (requerimiento de identificación de personas), 17 (restricción del tránsito y controles en las vías públicas), 18 (comprobaciones y registros en lugares públicos), 20 (registros corporales externos), 22 (uso de videocámaras), o 28 (control administrativo sobre armas, explosivos, cartuchería y artículos pirotécnicos), de esa ley, la situación puede ser perfectamente transformable inmediatamente de lo administrativo a lo penal y procesal penal (por ejemplo, de la identificación a la detención, aplicándose a partir de la misma las normas previstas en la CE, el CP y la LECRIM).

Me fijaré en el requerimiento para la identificación de personas por ser el más llamativo. Pues bien, el requerimiento para identificación que implica retención de la persona consistiría exclusivamente en el acto comprendido entre la constatación de que la persona no puede ser identificada o se niega a hacerlo, la llevanza o acompañamiento a comisaría y la realización de la diligencia de identificación, pero en contra de su voluntad, porque si lo hace voluntariamente, no hay coerción, no se alcanza el "status" de detenido. No puede durar más de seis horas, y el afectado debe ser informado de la causa de su llevanza a comisaría (art. 16.2 y 4). Después de ello, o se le pone en libertad, o se le lleva a presencia judicial. No hay alternativa (art. 16.5).

Si esto es así, la retención sería una clase especial de detención, porque para poder detener a una persona se ha de dar alguno de los presupuestos del art. 490 LECRIM, 
según el art. 492-1. ${ }^{\circ}$ y, sobre todo, según el art. 492-4. ${ }^{\circ}$ LECRIM. Y si no se dan esos presupuestos, estamos ante una detención ilegal.

Obsérvese además que no se ha derogado o modificado ni uno solo de los preceptos que la LECRIM dedica a la detención, pero el TC ha dicho que entre la libertad y su privación no existen zonas ni parcelas jurídicas intermedias (S TC 98/1986, de 10 de julio). Por tanto, si estamos ante privación gubernativa de la libertad, se viola el art. 25.3 CE; si es privación de libertad preordenada ante un futuro proceso penal, estamos ante detención (arts. 17.2 CE y 492 LECRIM), con lo cual, el art. 16 LSC no hace ninguna falta, porque ya existen normas ordinarias para permitir hacer lo que este precepto prevé.

Finalmente, nada se dice en el art. 16 LSC sobre el derecho de defensa, aunque es menos claro que esto sea inconstitucional, porque lo que exige la CE (art. 17.3) es que se interrogue a los detenidos en presencia de su Abogado, no que se les tenga que identificar ante él. Esto es competencia exclusiva de la Policía.

Estos argumentos no han sido admitidos por el TC en la Sentencia repetidamente citada. Para éste, la retención para identificación, en cuanto entraña un acompañamiento a los agentes, significa efectivamente una privación de libertad, que no deja de serlo incluso aunque el afectado la acepte (opinión concordante con la Jurisprudencia del TEDH: S 18 de junio de 1971, caso DE WILDE, OOMS Y VERSYP). Pero esta detención no es una detención preventiva. Ahora bien, sigue diciendo el TC, esta privación de libertad es conciliable con el art.17.1 CE, puesto que el art. 20 LSC afecta a personas no identificadas de las que razonable y fundadamente pueda presumirse que se hallan en disposición actual de cometer un delito o falta (y así lo reconoce el art. 16.1).

Finalmente, concluye el TC afirmando que como tal privación de libertad, le afectan determinadas garantías previstas en el art. 17.2 y 3 TC, pero no todas: La retención debe durar el tiempo imprescindible para realizar las averiguaciones de identificación, y se le debe informar al retenido de las razones por las que se le priva de libertad; pero no tiene derecho a guardar silencio, ni tampoco a la defensa técnica (abogado), porque la medida no prevé un interrogatorio policial, sino tan solo una averiguación de datos personales.

\section{Obtención de pruebas mediante filmaciones videográficas.}

La LO 4/1997, de 4 de agosto, permite que las Fuerzas y Cuerpos de Seguridad filmen y graben mediante videocámaras lo que ocurre en lugares públicos, como calles o plazas, sean abiertos o cerrados (art. 1.1). Esta posibilidad, indiscutiblemente de carácter preventivo, está directamente pensada para proteger la seguridad ciudadana, erradicar la violencia callejera y garantizar la seguridad pública, incluso en materia de circulación vial, pero puede convertirse en un acto de investigación si, como consecuencia de la filmación, se detecta la comisión de un delito, o coadyuva al descubrimiento de su autor. 
Este último aspecto es el que nos interesa. Hasta dicha LO, nada disponían las leyes españolas. Fue la jurisprudencia, y en concreto la del TS, la que sentó las bases de autorización de las filmaciones videográficas y obtención de fotos, particularmente en su importantísima Sentencia de 6 de mayo de 1993 (RA3854), que distinguió entre filmaciones de lugares públicos y privados.

Partiendo de la idoneidad del medio para averiguar los hechos criminales, el TS entendió que las filmaciones y fotografías obtenidas por la Policía desde puestos de vigilancia públicos, es decir, situados en la calle o en lugares públicos, en donde se hacía el seguimiento de personas que pudieran estar relacionadas con el hecho que es objeto de la investigación, eran perfectamente ajustadas a derecho, y para nada afectaban al derecho fundamental a la intimidad personal y a la propia imagen de las mismas, ya que éstos no son derechos absolutos o ilimitados, sino que deben ceder ante los intereses públicos de la persecución penal, de mayor importancia en estos casos. El fundamento legal hasta 1997 se encontraría en los arts. 8 de la LO 1/1982, de 5 de mayo, y en el art. 282 LECRIM. V. también la S TC 190/1992, de 16 de noviembre; y las SS TS de 23 de noviembre de 1990 (RA 9148), de 5 de noviembre de 1993 (RA 8279), de 14 de enero de 1994 (RA 12), y de 27 de febrero de 1996 (RA 1394). La LO 4/1997 ha recogido la jurisprudencia en lo esencial, estableciendo medidas de persecución penal y actuaciones de carácter administrativo, intentando respetar al máximo los derechos fundamentales implicados (art. 2).

La instalación de videocámaras se autoriza, previo informe favorable de una comisión presidida por un Magistrado (art. 3.1), que es vinculante si estima que podrían violarse los criterios de autorización del art. 4 (art.3.3), por la autoridad administrativa (el delegado del gobierno, art. 3.2), mediante resolución motivada (art. 3.4), que es recurrible administrativamente (art. 11).

La importancia práctica de la ley, que afecta directamente a la policía judicial, es que por motivos de urgencia máxima, o de imposibilidad de obtener la autorización, ésta puede instalar videocámaras móviles, dando cuenta en el plazo de 72 horas al máximo responsable provincial de las FCS (art. 5.2, III).

La utilización de videocámaras o de cualquier otro aparato análogo (art. 1.2), estará presidida por el principio de proporcionalidad, en su doble versión de idoneidad y de intervención mínima (art. 6). Si el resultado de la investigación, es decir, la grabación concreta de imagen y sonido, muestra apariencia de delito, hay que dar parte inmediatamente a la autoridad judicial, en todo caso, en el plazo máximo de 3 días, remitiéndole la Policía el correspondiente atestado (escrito o verbal), que incluirá el soporte original íntegro de la filmación (art. 7.1), que aunque nada diga esta LO al respecto tiene indiscutiblemente al menos valor de denuncia, pudiendo convertirse en prueba si en el acto del juicio oral declaran los agentes que la realizaron, y, por tanto, siendo elemento probatorio suficiente para obtener una condena penal.

El tratamiento de la filmación se quiere por la LO que sea absolutamente reservado (art. 7.2 y 3), debiendo ser de conocimiento público su instalación si son videocámaras fijas, aunque sin decir el lugar exacto de su emplazamiento (art. 9.1). El propie- 
tario del edificio está obligado a autorizar su colocación si ha sido seleccionado por la Policía (DA 6. ${ }^{\mathrm{a}}$ ). Pero cuando la grabación videográfica pueda afectar al espacio privado de la intimidad de una persona, como sería el caso de su domicilio, solo puede realizarse si previamente ha sido autorizada por el juez competente, o consentida por el interesado (art. 6.5).

Las filmaciones no se destruyen mientras sean objeto de investigación o de prueba en un proceso penal (art. 8.1), pudiendo los interesados pedir su visionado o cancelación, bajo determinados presupuestos (art. 9.2). Téngase en cuenta el nuevo art. 588 quinquies a) LECRIM, introducido también en 2015, sobre captación de imágenes en lugares o espacios públicos, que complementa ahora estas previsiones.

\section{Conclusiones}

Por las razones expuestas, concluyo brevemente reafirmándome de manera muy tenaz en:

Primero: La necesidad de afrontar un verdadero modelo policial válido para una investigación eficaz del crimen y, por tanto, plenamente homologable en América Latina respecto a los países más desarrollados jurídicamente del mundo.

Segundo: Ese modelo exige leyes modernas (de policía naturalmente, pero sobre todo de organización de los tribunales, de ministerio público, de procedimiento penal y también un nuevo código penal), que aseguren un funcionamiento correcto de una policía judicial verdaderamente autónoma respecto a los demás poderes del Estado; un presupuesto equilibrado que favorezca su formación cultural, jurídica y técnica, así como las dotaciones personales y materiales necesarias, garantizando por supuesto salarios dignos; $y$, finalmente, una toma de conciencia por parte de todos los ciudadanos y en especial por parte del Poder político, de que la policía judicial es una institución pública del Estado muy especial, clave para la consolidación y fortalecimiento de la democracia por las funciones que le corresponden en el proceso penal propio de un Estado de Derecho.

Tercero: Una vez conseguido ello, su formación y capacitación debe ser la siguiente preocupación del Estado, para conseguir en la ejecución de sus deberes una corrección legal exquisita, de manera que nunca puedan ser los causantes de exclusiones de prueba por vulneración de derechos fundamentales de los ciudadanos.

Solo así estaremos en mi modesta opinión de condiciones de afrontar verdaderamente una lucha eficaz contra el delito, una de las principales exigencias sociales públicas en cualquier democracia.

\section{Referencias}

AA. VV. (1987). Policía y Constitución, Serie Protección Ciudadana N. ${ }^{\circ} 1$. Barcelona: Ayuntamiento de Barcelona. 
AA. VV. (1990). Estudios de Policía Científica, 2 tomos. Madrid: Ed. Dirección General de la Policía.

AA. VV. (1991). Jornadas sobre Policía y Seguridad: Análisis jurídico-público. Oñati (Guipúzcoa): Ed. IVAP.

AA. VV. (1993). El moderno atestado policial. Madrid: Academia Editorial Lamruja.

AA. VV. (2009). Manual Único de Policía Judicial. Bogotá: Fiscalía General de la Nación, República de Colombia.

Alonso, F. (1996). Intervención del abogado ante la Policía Judicial. Madrid: Dykinson.

Ambos, K., Gómez, J. L. y Vogler, R. (2003). La policía en los estados de derecho latinoamericanos. Bogotá: Instituto Max-Planck para el Derecho Penal extranjero e internacional y Ediciones Jurídicas Gustavo Ibáñez.

Arciniégas, G. A. (2001). Policía Judicial y nuevo Código de Procedimiento Penal. Bogotá: Nueva Jurídica.

De Antón y Barberá, F. y De Luis y Turégano, J. V. (2012). Policía Científica (5 ed.). Valencia: Tirant lo Blanch.

Escalante, J. (Coord.) (2011). Manual del Policía. Madrid: La Ley.

Garrido, V. y Luque, R. (1990). Policía y ciencias sociales. L'Eliana, Valencia: Instituto Valenciano de Seguridad Pública.

Gómez, J. L. (1985). El proceso penal alemán. Introducción y normas básicas. Barcelona: Ed. Bosch.

Gómez, J. L. (1993). La Policía Judicial en España: Aspectos orgánicos y procesales penales. Justicia: Revista de derecho procesal (3-4), 389-416.

Gómez, J. L. (1993). El proceso penal español para no juristas. Valencia: Ed. Tirant lo Blanch.

Gómez, J. L. (2014). Los retos del proceso penal ante las pruebas que requieren tecnología avanzada: el análisis de ADN. En J. L. Gómez Colomer (coord.): La prueba de ADN en el proceso penal (pp. 23-67). Valencia: Tirant lo Blanch.

López, D. (1987). El aparato policial en España. Barcelona: Ariel.

Marchal, N. (Coord.) (2009). Código de Policía Judicial. Madrid: Aranzadi-Thomson Reuters.

Martín, P. (Dir.). (2006). La actuación de la policía judicial en el proceso penal. Madrid: Marcial Pons.

Martínez, R. (2001). Policía Judicial y Constitución. Pamplona: Aranzadi-Ministerio del Interior. 
Morales, A. (1988). Administración policial española. Madrid: San Martín.

Queralt, J. (2000). Introducción a la Policía Judicial. Barcelona: Bosch.

Rico, J. M. \& Salas, L. (1988). Inseguridad ciudadana y Policía. Madrid: Tecnos.

Rico, J. M. (1983). Policía y Sociedad Democrática. Madrid: Dirección de Seguridad del Estado, Ministerio del Interior.

Roxin, C. (2001). Derecho Procesal Penal, trad. G. Córdoba y D. Pastor. Buenos Aires: Editores del Puerto.

Sala, C. (1999). La Policía Judicial. Madrid: McGraw Hill.

Silva, G. (2003). Experiencias de unificación de cuerpos de policía. Seminario Internacional sobre Investigación criminal. Memorias. Bogotá: Universidad Externado de Colombia.

Turrado, M. (1985). Introducción a la Historia de la Policía, Madrid: Dirección General de Policía.

Rico, J. M. (Comp.) (1983). Policía y Sociedad democrática. Madrid: Alianza.

Zambrano, P. M. (1996). La Policía Judicial y sus funciones en la legislación penal. Bogotá: Ibáñez. 